\title{
Charting by Chaplains in Healthcare: White Paper of the European Research Institute for Chaplains in HealthCare (ERICH)
}

\author{
Anne Vandenhoeck ${ }^{1}$, Joost Verhoef ${ }^{2}$, Daniel Nuzum ${ }^{3}$, \\ Pascal Mösli ${ }^{4}$, David Neuhold ${ }^{5}$, Simon Peng-Keller ${ }^{6}$, \\ Traugott Roser ${ }^{7}$, Linda Ross ${ }^{8}$, Wim Smeets ${ }^{9}$, Austyn \\ Snowden ${ }^{10}$, Wilfred McSherry ${ }^{11}$
}

Abstract: "If it is not charted: it did not happen." The charting of healthcare chaplaincy contacts in patient files has been controversially discussed in the literature in recent years. In particular, entries in digital medical records raise questions among

1 Prof. Dr. Anne Vandenhoeck, Faculty of Theology and Religious Studies, KU Leuven, Belgium. anna.vandenhoeck@kuleuven.be

2 Dr. Joost Verhoef, OLVG General hospital, Amsterdam, The Netherlands. j.h.a.verhoef@ olvg.nl

3 Dr. Daniel Nuzum, Cork University Hospital \& University College Cork, Ireland. Daniel.nuzum@ucc.ie

4 Pascal Mösli, Faculty of Theology, Domain Spiritual Care, University of Zurich, Switzerland.contact@pascalmoesli.ch

5 Dr. David Neuhold, Faculty of Theology, Domain Spiritual Care, University of Zurich, Switzerland. david.neuhold@uzh.ch

6 Prof. Dr. Simon Peng-Keller, Faculty of Theology, University of Zurich, Switzerland. simon.peng-keller@uzh.ch

7 Prof. Dr. Traugott Roser, Faculty of Protestant Theology, WWU Münster, Germany. traugott.roser@uni-muenster.de

8 Prof. Linda Ross, School of Care Sciences, Faculty of Life Sciences \& Education, Pontypridd, Wales, UK. linda.ross@southwales.ac.uk

9 Dr. Wim Smeets, Radboud UMC, Nijmegen, The Netherlands.wim.smeets@radboudumc. $\underline{\mathrm{nl}}$

10 Prof. Austyn Snowden, School of Health and Social Care, Edinburgh Napier University, United Kingdom. A.Snowden@napier.ac.uk

11 Prof. Wilfred McSherry, School of Health, Science and Wellbeing, Staffordshire University/University Hospitals of North Midlands NHS Trust, United Kingdom. w.mcsherry@ staffs.ac.uk 
pastoral care managers about confidentiality, data protection regulations and managerial interests.

The European White Paper on charting in healtcare chaplaincy argues that charting chaplaincy contacts with patients and relatives (1) makes their spiritual needs visible, (2) contributes to improved interprofessional communication about chaplaincy and (3) makes the work of chaplains transparant. Charting improves the quality of care for patients, promotes the professionalism of chaplaincy and facilitates interdisciplinary exchange and multi-professional cooperation. It should be noted that entries in patient files should be made as if the patient were reading them. Descriptions must be adequate, understandable and concrete: The reason for the contact, assessment, changes resulting from the contact, interventions made and further planning are five steps of patientcentred pastoral care documentation. They respect patient rights and the principles of clinical ethics. In each case, questions of the software used, access rights and the use of the collected data material need to be clarified.

The documentation of chaplaincy contacts can improve the relationship between patient and chaplain if it is included in the care. Last but not least, chaplaincy charting creates a data basis for practice-oriented research and training and for the development of the profession.

Key Words: health care chaplaincy, spiritual care, charting spiritual care interventions

Zusammenfassung (Deutsch): "Was nicht dokumentiert ist, ist nicht geschehen". Das Dokumentieren von Seelsorgekontakten in Patientendossiers wird in den letzten Jahren kontrovers in der Literatur diskutiert. Insbesondere Eintragungen in digitalen Krankenakten werfen unter Seelsorge-Verantwortlichen Fragen der Vertraulichkeit, der Datenschutz-Regelungen und hinsichtlich der leitenden Interessen auf.

Das White Paper argumentiert, dass das Dokumentieren seelsorglicher Kontakte mit Patient ${ }^{*}$ innen und Angehörigen 1) deren spirituelle Bedürfnisse sichtbar macht, 2) zu einer verbesserten interprofessionellen Kommunikation über seelsorgliche Begleitung beiträgt und 3) die Tätigkeit der Seelsorge nachvollziehbar macht . Dokumentieren verbessert die Qualität der Versorgung von Patient*innen, fördert die Professionalität von Seelsorge und erleichtert interdisziplinären Austausch und multiprofessionelle Kooperation. Zu beachten ist, dass Eintragungen in Patientenakten so erfolgen sollen, als lese der ${ }^{\star}$ die Patient ${ }^{*}$ in mit. Beschreibungen müssen adäquat, verständlich und konkret sein: Anlass des Kontakts, Assessment, Veränderungen aufgrund des Kontakts, erfolgte Interventionen und weitere Planung sind fünf Schritte einer patientenzentrierten Seelsorgedokumentation. Sie achten Patientenrechte und die Prinzipien klinischer Ethik. Jeweils zu klären sind Fragen der verwendeten Software, der Zugriffsrechte und der Verwendung des gesammelten Datenmaterials.

Das Dokumentieren von Seelsorgekontakten kann die Patienten-SeelsorgerBeziehung verbessern, wenn es mit in die Begleitung einbezogen wird. Nicht zuletzt entsteht durch seelsorgliche Dokumentation eine Datengrundlage für praxisnahe Forschung und Ausbildung und für die Entwicklung der Profession.

Schlagworte: Seelsorge, Spiritual Care, Seelsorge Dokumentation 
Samenvatting (Nederlands): The European Research Institute for Chaplains in HealthCare (ERICH) heeft in 2021 een White Paper geschreven over registratie door spiritueel zorgverleners/geestelijk verzorgers in elektronische patiëntendossiers en deze voorgesteld tijdens de online consultatie van het ENHCC. Elektronisch registreren is een complexe zaak en de White Paper poogt om structuur en samenhang te brengen in de vele aspecten die hiermee te maken hebben. Het document geeft eerst redenen op waarom registreren belangrijk is vanuit het perspectief van patiënten, spiritueel zorgverleners/geestelijk verzorgers en interdisciplinair samenwerken. In een volgend deel worden overwegingen aangeboden rond belangrijke aspecten van registratie: Is er een theoretische onderbouw? Welke taal wordt gebruikt? Hoe draagt het bij tot interdisciplinair werken en wat met vertrouwelijkheid? Kan er in afspraak met patiënten worden geregistreerd? De praktijk van registratie in Europa is erg verschillend. In deel 4 van de paper worden bepalende factoren daarvoor aangehaald. Een vijfde deel behandelt motivaties om voor een bepaald model van registratie te kiezen. Nadien worden aanbevelingen gegeven om het proces van registratie in de verschillende Europese landen te formaliseren. Een laatste deel geeft een update over onderzoek rond registratie. In een addendum kan de lezer een beschouwing vinden over de reacties van de deelnemers aan de consultatie van ENHCC op de White Paper.

Trefwoorden: geestelijke verzorging, spirituele zorg, registratie in elektronische patiëntendossiers

Résumé (Français): L'Institut européen de recherche pour les aumôniers dans les soins de santé (ERICH) a rédigé un White Paper sur le conseilleur spirituel et le partage d'informations dans les dossiers médicaux électroniques et l'a présenté lors de la consultation de l'ENHCC. L'enregistrement électronique est une question complexe et le WP tente d'apporter structure et cohérence aux nombreux aspects concernés. Le document donne d'abord des raisons pour lesquelles l'enregistrement est important du point de vue des patients, des conseilleurs spirituels et de la collaboration interdisciplinaire. Dans une section ultérieure, des considérations sont proposées concernant les aspects importants de l'enregistrement : Existe-t-il un fondement théorique ? Quelle langue est utilisée ? Comment contribue-t-elle au travail interdisciplinaire et qu'en est-il de la confidentialité ? L'enregistrement peut-elle se faire en accord avec les patients ? La pratique de l'enregistrement en Europe est très différente. La partie 4 du document cite des facteurs déterminants à cet égard. Une cinquième section traite des motivations pour le choix d'un modèle d'enregistrement particulier. Suivent des recommandations visant à formaliser le processus d'enregistrement dans les différents pays européens. Une dernière section met à jour les recherches sur l'enregistrement. Dans un addendum, le lecteur trouvera une réflexion sur les réactions au WP des participants à la consultation de l'ENHCC.

Mots clés: soin spirituelle, conseilleur spirituelle, l'enregistrement dans les dossiers médicaux électroniques 


\section{Introduction: Writing the White Paper}

\section{Background}

During the past years, the issue of documenting spiritual care by chaplains has featured regularly in European and international research literature. Researchers in chaplaincy studies in Switzerland received funding for a project on charting in 2018 that would last several years. The European Research Institute for Chaplains in HealthCare (ERICH) was involved in parts of the Swiss project and wanted to research further how patients see and experience charting by chaplains.

\section{Process}

ERICH brought together members of the Swiss chaplaincy research team with researchers from Belgium, Germany, Ireland, The Netherlands and the UK. Rather than starting with empirical research on the perspective of patients regarding charting by chaplains, the need was felt to write a White Paper first that would gather and structure information, take a position, present best practices and increase reflection among European chaplains. The experts present were willing to form a group that would produce a White Paper. Several online meetings were planned and dedicated to discussing all items related to documenting spiritual care.

\section{European Network for HealthCare Chaplains (ENHCC)}

Small groups were formed to write parts of the White Paper. Those writings were discussed, adjusted and finally brought together through an editing process. The White Paper was then introduced and discussed during the online consultation of the European Network for HealthCare Chaplains (ENHCC) on 14 May 2021 as part of a consultative stakeholder engagement process with European healthcare chaplains. The reception by the participants of the ENHCC consultation was in general very positive and led to a number of additions and corrections in the White Paper and a final editing. The reader can find more on the reception by the participants of the ENHCC consultation and on their good practices of charting in Annex 1.

\section{Charting by Chaplains in Healthcare}

\section{Why a White Paper?}

A White Paper aims to present information in order to understand a complex issue, invite opinions, inspire reflection and also to propose ways of 
acting. As documenting is a complex issue in contemporary healthcare chaplaincy, this paper aims to bring some structure and cohesion to the many aspects that are connected with documenting and also to include principles of record keeping. The initiative to write this White Paper is taken by ERICH, founded by ENHCC. We chose to write a European White Paper as it is already complex to take into account the variations in ethical, legal, spiritual care, healthcare and cultural aspects that determine documenting within Europe. Within the European context, charting is increasingly a topic of research as the Swiss project has shown in 2018-2021 (Peng-Keller \& Neuhold, 2020).

Chaplaincy and healthcare are two evolving realities. To secure and broaden their impact, chaplains need to be integral members of interdisciplinary healthcare teams. One of the reasons they are often not is terminology. For example, Massey et al. (2015) and Carey and Cohen (2015, p. 1773), suggest that if chaplains could talk a "common language" then the evidence base would be further enhanced because chaplains would all be naming the same concepts in the same way, and so evidence acquired on one side of the world would be mutually understood and where appropriate transferred to the other because everyone would be using the same language. Another key and related issue is documentation. Similar words are "record keeping" or "charting" (Peng-Keller \& Neuhold, 2020).

Chaplains have been documenting for a long time, for example from the earliest days of Clinical Pastoral Education (CPE), and more recently charting has progressed to an electronic medium in electronic patient files and healthcare records. Contemporary healthcare is making documenting more important and more challenging. The whole process of digitization, electronic patient files, the recent data protection law of the EU, the need for interdisciplinary care, the increasing autonomy of patients in healthcare and the need for chaplains to be accountable are but a few of the aspects this White Paper shall touch upon which make charting in spiritual care enriching and challenging at the same time. Charting can take on different forms: by checking boxes or by narrative charting or both, by documenting for yourself as a chaplain or for your colleagues or for the interdisciplinary team, in a file that can be partially or fully read by the patient. Some forms of charting are built on theoretical foundations, others have organically grown out of the practice. All these different forms present their own possibilities and challenges.

The White Paper starts from the necessity of charting by chaplains in contemporary healthcare because of the relevance of spiritual care for whole person care. This is manifested by a growing body of research showing for example the impact of spiritual distress and spiritual resources on medical 
treatment or the impact of care for spiritual needs on patient satisfaction. Documenting spiritual care will (1) make the spiritual needs of patients and those around them visible, (2) optimize communication on chaplaincy care meeting spiritual needs of patients and those around them, and (3) make the contribution of spiritual care visible.

This paper will use the word "charting" for taking notes that describe the spiritual care between a chaplain and a patient or family member and more specifically notes that reflect the language patients use as well as their stories. We will use the term "chaplains" to refer to those persons who are hired by health facilities or faith groups to provide spiritual care to patients, family members and staff. They are trained and educated to be specialists of spiritual care in the context of healthcare. We also use the term "patient" to refer to those who are cared for in nursing homes, hospitals, hospices, mental health centres or centres for people with disabilities and are in need of physical, emotional, social and spiritual care.

The authors are aware of the concerns of some chaplains towards documenting spiritual care mainly out of issues relating to confidentiality, identity and integration in healthcare. Some chaplains have no access to charting because they are employed by a faith community and not by a healthcare institution or are mainly seen as representatives of faith communities and not as part of a healthcare team. We hope this paper serves the chaplaincy profession in an number of ways: (1) encourages chaplains who chart, those considering charting and those not currently charting to reflect on their stance, (2) broadens the scope of professional arguments and application of research knowledge and (3) extends application of what the White Paper offers to other forms of documentation by chaplains such as charting on paper.

The White Paper consists of seven chapters. The above motivation for a White Paper is followed by a statement on the importance of charting. Fundamental considerations and different aspects of documentation are presented before different models are examined and recommendations are offered. An overview of referred to research precedes an annex describing the reception of the White Paper by European chaplains and chaplaincy associations.

\section{Why is Charting Important?}

Charting is important to improve spiritual care in several ways. It contributes to better care for patients, to the professionalism of the chaplain, to interdisciplinary cooperation and to policy on spiritual care. 


\section{A. Better Care for Patients}

The first and main purpose of charting is to improve spiritual care for patients. The contribution to the mental and spiritual well-being of patients depends basically on the quality of the interaction between the chaplain and the patient, individually or in groups, virtually or face-to-face. But the written account of what has taken place is also important. First, through charting, the chaplain can give a voice to the patient's story and their existential, spiritual and religious needs in the electronic or paper-based healthcare record, and the language the patient uses, so that every professional can take this into account and provide patient-centred care. It doesn't matter whether these notes are more narrative nature or divided in sections. Second, charting helps chaplains to reflect on their own actions; thus, the patient meets a chaplain who acts deliberately and consciously. Third, charting promotes continuity of care. The patient is assured of a good follow-up in the future by the same or another chaplain or another professional to whom the care is transferred (for example home care).

\section{B. Professionalism of Chaplains}

What chaplains report provides insight into their interaction with patients and also into the reflection on their job. Charting stimulates chaplains to reflect on all aspects of their professional actions: the goals, the counselling method, other interventions and the effects of their actions. Accountability is most basically translated into the simple question: "what have you discussed with the patient (or his/her loved ones) and what have you done so that I can continue with it when I meet the patient?"

From this perspective also arose the need for spiritual screening and diagnosis, in order to discuss the "spiritual impressions" that have been gained (Smeets \& de Vries, 2016). Charting helps to orient joint reflection with fellow chaplains. The international CPE movement has been an important incentive for analysing and reflecting on charting by chaplains. It contributes to improvement of counseling skills and professional identity of the spiritual caregiver. In some contexts, for example in forensic institutes, reading charts and documenting spiritual care is a prerequisite for patient and staff safety. Research also highlights that charting provides greater insight into the nature and effect of the work of chaplains. But before such research is properly shaped, the reporting must be more extensive - and therefore more time-consuming - and according to a mutually agreed format and (sufficient) content (Smeets \& de Vries, 2020). 


\section{Interdisciplinary Cooperation}

Sharing of information within chaplaincy and between professions is important for a number of reasons. First, it enables the provision of person-centred care, which is joined up and integral, not fragmented or conflicting. Second, the whole team has sight of what's most important to the person and each discipline can channel its specialist expertise into working towards the same shared goal. Blending of the "science" and the "art" of the different professions is an added benefit, bringing a balanced whole person approach to care provision (Ross \& McSherry, 2010). Third, solo working is minimized.

This integrated or "team" approach to care has many benefits:

1. More effective care: conflicting interventions will be minimized with everyone working towards the same outcome.

2. More efficient and prudent care: only what is most important to the patient is addressed-for example by using a tool such as the 2Q-SAM (The Ross \& McSherry 2 Question Spiritual/Whole person Assessment Model, Ross \& McSherry, 2018).

3. Greater patient satisfaction (Balboni et al., 2017; Ross \& Miles, 2020; Steinhauser et al., 2017) and staff resilience (Snowden et al., 2020).

This way of working assumes that all disciplines are prepared to share with each other. However, chaplains are not always considered part of the interdisciplinary team. The reasons are complex, but include concerns and complexities around boundaries, disclosure, confidentiality, data protection, data privacy and fear of litigation (Ross \& McSherry, 2020; Ross et al., in press).

\section{Spiritual Care Policy}

Charting is a good basis for chaplains to take leadership and control of their own work. Charting also offers a team of chaplains insight into their own activities and helps them to make choices in that way. Finally, charting offers concrete data with a view to accountability of their work as contributing to the quality assurance and policy of spiritual care departments and of the organization (Smeets et al., 2011). Ultimately, charting helps professional associations to integrate the contribution of the discipline into national care policies. 


\section{Considerations for reflection on chaplains charting}

\section{A. Foundations}

It is important to note that the movement of $\mathrm{CPE}$ was from the very beginning supportive of charting: clinically trained chaplains should be part of the healthcare team and document their experiences in clinical records. CPE encompassed, therefore, forms of record keeping for at least three different purposes: for personal reflection, supervision, and interprofessional communication. Russell L. Dicks, a pioneer in modern pastoral care, stated in 1940: "This is a brief note, similar to that which the consultant writes, which is simply a record of the chaplain's impression of the patient. The chaplain often discovers significant things about a patient which the physician needs to know; these discoveries as well as impressions should be available in the record." (Dicks, 1940)

The "significant things" must be recorded in the medical documentation so that they are not lost. "If it wasn't charted it didn't happen." This expression, often used in healthcare, expresses that documentation serves to select from the wealth of daily observations, analyses, findings, actions, and effects those that are considered essential in the community of professionals to best support patients. The dimensions of care that are not documented risk evading clinically shared attention. Chaplains' documentation thus helps to ensure that essential dimensions of the patient's data are perceived and remembered.

If chaplaincy is to communicate its content interprofessionally through an existing electronic documentation system as part of quality control systems, it faces two challenges:

- When charting in electronic patient files, chaplains enter a system based on underlying (medical) paradigms. Their first challenge is to adapt while retaining the distinctiveness of spiritual care.

- Presenting the specialist spiritual perspective of chaplaincy in such a manner that it is comprehensive and helpful to other professions.

When analysing existing chaplains' documentation systems, it does not always seem clear which theoretical - if any - understanding is guiding.

\section{B. Whole Person Care and Interprofessional Charting}

Chaplaincy brings its own perspectives and its own methods, communication style, hermeneutics and understanding into the interprofessional collaboration and documentation. For example, it distinguishes between curing and healing; it is particularly interested in patients' narratives, and 
it examines the spiritual dimensions of phenomena such as fear and despair. In this way, it expands the bio-psycho-social understanding of health to include the spiritual dimension. The question here is whether the terminology is clarified within chaplaincy and also between chaplains and the other healthcare professionals.

The use of language appears throughout this white paper as an important consideration. Language has the capacity to describe, to interpret and to create the reality of spiritual care. The language used by chaplains to document their care, should be:

- Descriptive by noting sense observations, quoting patients, recording feedback by patients, describing behaviors.

- Accessible by using everyday language, avoiding jargon.

- Concrete and informative by giving necessary information to the interprofessional team, by stating who will follow up on the patient and when.

Even within healthcare chaplaincy, there is currently neither standardized language for spiritual concerns, interventions, and outcomes, as recent research in the field testifies (Ross \& McSherry, 2020). Nor does there exist a common understanding for achieving inter-professional consensus on terms such as "hope", "anxiety" or "distress". Chaplaincy specific usage of terms like "hope" and "anxiety" raises the question of whether shared terminology and shared conceptional application can in fact improve inter-professional communication (Johnson et al., 2016). Furthermore, interprofessional consensus on terms will not only facilitate communication between different members of the care team, but potentially help measure the impact of care itself. Finally, in all these questions concerning language, the language of the patients themselves must be taken into account. It is one of the concerns of chaplaincy to express the language and understanding of the patients themselves.

\section{Prerequisites for Interprofessional Cooperation}

Spiritual care documentation should present the chaplain's contribution to patient care in such a way that other professions can quickly recognize and utilize it to improve their care. In order to achieve the summary of a chaplain's intervention and assessment, it is necessary to link to communicative structural elements that are common in healthcare.

Chaplain documentation should include the following structural elements which are mostly mentioned in current literature: first, the data 
describing the patient's situation as well as the referral reason; second, the assessment mentioning the spiritual concerns and resources in the current treatment situation; third, the interventions describing the actions of the chaplain; fourth, the effect or outcomes of the interventions; and fifth, the intended continuation of the care (plan of care).

The description of the outcomes is particularly important and difficult: On the one hand, describing the effect of spiritual care interventions communicates to the treatment team how they may affect the patient's wellbeing. But they are also a way for the spiritual care team to critically review the impact of their own activities. Montonye and Calderone (2010) found that chaplains' recording of hospitalized patients' feedback was more descriptive of the chaplains themselves than informative from the patient's perspective. Chaplains' self-reported data may be subject to self-report bias, and chaplains may tend to over-report positively perceived experiences. Careful review and description of the impact of chaplaincy interventions helps to provide a realistic assessment of their actions that is open to discussion.

In order for spiritual care documentation to actually promote an interprofessional perspective and collaboration, education and binding forms of collaboration are needed. That means that educational efforts within chaplaincy, as well as educational opportunities for other health professionals can improve and evaluate their understanding of the content of documentation. Charting spiritual care both requires and inspires cultures of collaboration.

\section{Interdisciplinary Integration and Confidentiality}

For chaplains to be able to work together with other health professionals, spiritual care must be implemented, and chaplains must be integrated into the team to promote interprofessional exchange of information and consideration. Only in this way is it possible for observations of chaplains to flow into the joint care and for it, in turn, to receive impulses to provide spiritual care in the best possible way. The integration of spiritual care into interprofessional treatment teams, however, may be in some tension with maintaining chaplain's confidentiality vis-à-vis the patient. It should be emphasized that this tension is present for all professionals who share information.

It is therefore essential that only information relevant to the patient's treatment is communicated. Checkboxes are usually less problematic because they only contain standardized information. In the case of free text fields, it is helpful to imagine the patient looking over the documenter's shoulder. Documentation needs to be done in an attitude of appreciation and transparency towards the patient and in regard to the patient's right to information including his own documentation. The patient should be aware 
of the interprofessional communication community in which chaplaincy is integrated, and he/she should have the possibility to control the flow of information, i.e. also to ensure that certain information is not passed on to other professional groups or even to other chaplains. In that regard ethical criteria like informed consent, confidentiality, transparency, relevance, proportionality and accessibility are fundamental in the reflection on charting by chaplains.

\section{E. Caring Relationship and Open Notes}

The patient-chaplain relationship is fundamentally based on trust; this needs to be the underlying principle of charting spiritual care. A new form of documentation, which builds on the basis of trust and even aims to deepen it, is the so-called open notes. Open notes is an international movement promoting and studying transparent communication in healthcare (https://www.opennotes.org/). Its intention is to help patients and healthcare professionals share meaningful notes in medical records. Patient access to notes may offer a way to improve both patient engagement and quality of care. The concept of open notes, an initiative to allow patients to view the notes written by physicians, nurses, chaplains and other care providers, adds a new, more immediate demand for patient-centredness in clinical documentation. Although it is still too early to state with certainty how the increased transparency of open notes will change existing clinical documentation, the following changes - all of which are believed to be positive by provider and patient participants in pilots of the open notes initiative - are likely: avoidance of pejorative language in descriptions of patients, patient behaviors, and findings; increased documentation and clarity in documentation of care plans; and increased efforts at timely completion of notes.

\section{Aspects of Charting}

Chaplains chart to communicate about their care for patients so that it can be integrated in the team's care (interdisciplinary charting) and so that, if needed, this care can be continued by their colleagues (disciplinary charting). It can also be argued that chaplains chart for their patients, by hearing, interpreting and recording what is important to the patient as he/she navigates through ill health. Chaplains by charting capture the "story" of the patient in their healthcare record. This is a valuable dimension that catches and records the experience and unique story of the patient rather than an "illness-focused" approach. 


\section{A. What Are Determining Factors in How Chaplains Chart?}

\section{The Patient}

The philosophy of healthcare is moving more and more towards ownership by patients. This means that a patient's file is seen as the property of the patient, at least from an ethical perspective if not from a legal. When charting, chaplains need to start from the perspective that the patient is reading over their shoulders. This should inspire reflection on confidentiality and transparency (asking permission of patients to chart aspects of the visit). In some countries patients already have full access to their files, in others the access is limited. Patients' rights are a determining factor in how to deal with patients' files. However, in all cases chaplains should operate from the stance that a patient (or his/her family) will read the notes.

\section{The Software}

Although there is some discussion about a national file per patient that is accessible for everyone who is involved in the treatment, in most countries a patient's electronic file is kept within an individual healthcare facility. Hospitals and other healthcare facilities buy software, offered by different companies, or develop their own. As a consequence there is a lot of difference in the form and space provided for chaplains to chart. Sometimes the bought software comes with an integrated part for chaplaincy, sometimes it is lacking, sometimes the software is a rather basic frame where chaplains can add a module. When a healthcare facility is developing its own software, chaplains should be involved with regard to the integration of spiritual care. When no software is involved and charting happens in paper files, the other mentioned factors still determine charting.

\section{The Healthcare Facility}

Although chaplains are best seen as part of an interdisciplinary team, some managers start from the perception that chaplains are mere representatives from particular religions or beliefs. Some facilities therefore do not give permission to chaplains to consult patients' files or to chart. Others demand that chaplains chart as they aim to make the care they provide transparent in order to achieve quality standards. External quality control organizations will look at transparency and coordination of care to evaluate healthcare systems. In this context chaplains are perceived as accountable members of the healthcare team. Not charting or not charting parts of spiritual care is discouraged by management in the context of interdisciplinarity, accountability, quality control and efficiency. All healthcare facilities should recognize the importance of integrating their chaplains as full members of the 
interdisciplinary healthcare teams, and with that comes responsibilities on both the chaplain and the institution.

\section{Confidentiality}

Chaplains contribute significantly to healthcare. As such they are bound by confidentiality, protecting the patient's right to privacy. Patients entrust their stories to chaplains. Often religious traditions and laws influence the chaplain's and the patient's perception on confidentiality. Chaplains who belong to religious communities are part of religious traditions that hold confidentiality high, which in some religious traditions takes on the form of absolute confidentiality in the sacrament of confession. In return, despite the widespread secularization in Europe, many patients still link chaplains with confidentiality. This may be a determining factor for many chaplains in how and what to chart. Software that is used for electronic patient files can include a charting space for chaplains that is not accessible for others. If available, chaplains use it to make notes on what patients confided to them but do not want to be shared. Within an electronic environment the question can be raised if anything can really remain unshared. Most professional associations for chaplains have a code of conduct which always integrates rules and professional limits about confidentiality. In all cases chaplains should be transparent about the boundaries of confidentiality so that the patient can retain autonomy in what they may choose to share. When chaplains use private notes (on paper) they also have to be stored safely.

\section{Data Protection Laws Like GDPR (General Data Protection Regulation)}

GDPR is the EU data protection law which was put into effect in 2018. The data protection law applies to everyone who participates in processing the personal data of EU citizens or residents. Every member state of the EU needs to integrate the law in its systems and organizations. The law emphasizes the privacy rights of people and will continue to have an impact on the way we chart in healthcare.

\section{Charting Models}

There is no one model that European chaplains use for charting. Some chaplains tick boxes, some use preexisting codes, others use free text boxes or a combination of the previous possibilities. Some models are built on theoretical and/or theological underpinnings, others grew out of the practices of chaplains. The leading motive for any choice of model should be how it serves the communication about the patient's care best. 
The way chaplains in Europe are charting differs because of the legal context, the different types of software, the space offered by healthcare facilities, the many different models that are used and because of different perspectives on confidentiality (from strict to shared).

\section{B. How to Communicate and Chart in the Tension Between Sharing Information and Confidentiality?}

The following principles are important:

1. The patient's autonomy: what does the patient want and allow?

2. Beneficence: integral care integrates spiritual care in order to offer patients the best coordinated care.

3. Non-maleficence: being professional means being able to communicate about the given care and being accountable and to chart in a way that does not lead to mis-interpretation which may cause harm.

4. Transparency: chaplaincy needs to be visible, transparent and integrated.

5. Justice: functional charting where it is deemed necessary allows the chaplain to balance confidentiality and integrated care.

These criteria are based on ethical principles that put the interests of the patient and whole patient care first.

\section{What Kind of Models Are Out There and What Determines the Differences?}

\section{A. Different Objectives Lead to Different Models}

There are very different documentation models around the world. What they all have in common is that they take place in the interest of the best possible spiritual care for the patient. The direct recipients and the objectives associated are different. Four groups of recipients for documentation can be distinguished, which often overlap.

\section{Patients and Their Relatives}

The knowledge that the patient has the right to read the notes initially triggers a quality requirement: notes should be written keeping this in mind. It goes without saying that judgments about the patient are to be refrained from, as is the disclosure of knowledge or conjectures that have not been discussed with the patient. When the patient reads the notes, he/she should not be surprised, but should recognize himself/herself in everything, because he/she is aware of it, because he/she supports the documented decisions, 
and because he/she considers the information contained in the entries to be relevant to his/her situation in the hospital. The latest development even leads to documentation becoming part of the communication between patient and chaplain and thus part of chaplaincy care. For the patient and family members (who activate their right to see medical records), these records summarize how the patient is being treated as a respected human being regardless of any difficulties s/he may be seen as causing.

\section{The Chaplaincy Profession}

Documentation can serve to improve the quality of chaplaincy. For example, developing practice theory by analysing both effective and ineffective practice patterns has the potential to improve patient care and help identify potential strategies to prevent incidents or errors. The results can also be used for continuing education.

Documentation, however, can also be used to support spiritual care research. For example, charting can form a basis for a policy making and for researchers in spiritual care to carry out statistical operations and to come to an analysis of data. Policies such as care pathways or protocols can be changed in order to integrate spiritual care based on charting by chaplains. Charting can show that chaplains are regularly involved in certain patient groups or in certain circumstances. Research based on charting can be executed in order to answer questions such as: who is involved in the care of the patient, which spiritual interventions take place in visits with patients with certain diagnoses and is spiritual care a factor that determines the length of stay? Chaplains' charting can also be used to collect statistical material to strengthen their integration and position in hospitals. Charting can show the value of spiritual care through the interventions or outcomes that are used.

\section{The Disciplinary and Interdisciplinary Team}

The main motivation to chart in an electronic patient file is the contribution that disciplinary and interdisciplinary charting can offer to the best possible spiritual care. Furthermore, documentation will help create more visibility for the chaplain as a professional. Charting allows chaplains to demonstrate their reliability in responding to referrals and to educate their interdisciplinary colleagues regarding their role. Different contents and goals can be distinguished. In many existing documentation models, combinations of the following topics can be found: 
i. "The chaplain was there"

A basic task of documentation is to let the interdisciplinary team know that spiritual care took place and who the chaplain is to contact. This person can be contacted and referred to again. In the simplest form of documentation, the only thing noted is that the chaplain visited the patient. Sometimes it is mentioned what the topic of the accompaniment was and whether a follow up is planned.

ii. Spiritual needs and resources of the patient

Documenting selected content of the spiritual care assessment serves to integrate the spiritual dimension of the individual into healthcare. By noting spiritual needs and resources, the interdisciplinary team is informed of what might contribute to disrupting or enhancing the therapeutic process, thus promoting care of the whole person. .

\section{iii. Spiritual status}

In some models, spiritual distress and resources are not only recorded, but a diagnostic weighting or status description is also provided. The care team is told whether, from the spiritual care perspective, the current situation results in spiritual stress for the patient (and how high the stress level is to be assessed) that requires accompaniment.

\section{iv. Spiritual care activities}

Chaplains documenting assessment, interventions, outcomes and plan is part of the essential communication between care providers so as not to confront the patient with fragmentation and contradictions in diagnosis and treatment. The process of recording enables care providers to focus on what the patient most immediate needs are. The documentation allows for planning of the therapeutic process, as it not only records diagnosis and treatment, but has medical appointment scheduling functionality as well.

\section{v. Recommendations}

Finally, there are various forms of recommendation that can be found in documentation models. They range from general recommendations that concern the patient's perception to very specific recommendations that seek to influence the actions of other health professionals as well. Charting allows the chaplain to influence the therapeutic process in such a way as to better serve the interests of the patient - even if advocating them is contrary to the impressions of the therapeutic team - for instance by drawing attention to aspects of the patient's well-being that have been neglected so far. 


\section{Stakeholders}

The stakeholders of documentation by chaplains may include institutional management, health insurers, health authorities or state authorities. Documentation provides evidence of spiritual care provision and may be used as a measurement of service quality and as justification for funding. The content of the documentation refers to the requirements laid down in laws, ordinances and agreements. The level of detail required varies considerably.

In Quebec, Canada, spiritual care services receive their funding following the compilation of "units of measurement". The types of spiritual care intervention that qualify as units are listed in Ministère de la Santé et des Services sociaux du Québec (2010). For each unit of measurement reported, there must be a note in the medical file. In Victoria, Australia, the College of Chaplains requested the inclusion of pastoral care intervention codes for the Third Edition of ICD10-AM (National Centre for Classification in Health; World Health Organization 2002). In the USA, documentation of spiritual interventions is proof of compliance with regulatory requirements by the Joint Commission to provide for the spiritual needs of all patients. In the Kanton Bern in Switzerland the ordinance to Article 53 of the Hospital Care Act specifies the services provided by chaplaincy, which it must report in a performance report annually.

\section{B. Good Practices}

1. Checkboxes are the appropriate tool for the performance record as well as for many research projects. The required information is already given in the tool and can be quickly recorded. The information can be summarized and presented at any time.

2. For interprofessional communication, a mixture of checkboxes, in which summary, statistical information is recorded, and free text fields, in which the current situation is recorded, proves to be suitable.

3. The five-part model has become widely established for narrative charting in the free text fields: (1) reason for referral (by whom was spiritual care called in and for what reason?), (2) comprehensive spiritual assessment (spiritual needs and resources, concerns of the patient), (3) care provided (interventions of chaplain), (4) outcome (from the perspective of the chaplain and the patient), and (5) plan of care (continuation of chaplain support, recommendations to the team). The narrative should be clear, concise, and respectful (no intimate details and respecting the difference between need to know and nice to know). 
4. All information should be passed on in such a way that it is understandable and helpful for other professionals in order to provide whole person care. This requires a language, form and structure known in the healthcare system. A language needs to be used, that is "accessible" to those outside of chaplaincy, which is consistent with the understanding of the same terminology of other professions and contains no "code-language". At the same time, it should be a language that properly allows and expresses the spiritual dimension.

5. With regard to the patients, the following is essential: the documentation should not contain interpretations about the patients and their process, unless they themselves were part of the process, which was designed together with the patients and confirmed by them; the documentation must be characterized by appreciation for the patients and their process; the documentation preserves the patient's confidentiality. Would the patient/family see themselves in your note, agree with your assessment, and feel as if you upheld their humanity, personhood, and values?

\section{Final Recommendations}

In many European countries the current aim is to organize the spontaneous reporting practice by chaplains. We list the following recommendations for this process.

\section{A. Five Stepping Stones for Charting}

Whatever the system or form of charting, it is important that chaplains address the following aspects of the visit to the patient:

1. What was the reason for your visit?

2. What is your assessment of the patient?

3. What did you do in order to make a difference (interventions)?

4. What difference did your visit make?

5. How will you ensure possible further care (accountability/spiritual care plan)?

\section{B. Charting and Working With Patients' Stories.}

The patient's narrative is an important tool in the chaplain's work. In order to retain this narrative during the treatment of patients and to be able to refer to it, it is essential to keep notes and to voice as much as possible the storytelling by the patient. This contributes to patient-centred care. 
In most cases the shared part of the patient file is the most suitable place to chart, in view of the interdisciplinary team. When confidentiality should be addressed in a special way, chaplains can make use of a closed off part of the patient file or of another digital or paper form. These should be properly secured and must be kept in accordance with the legal archiving periods.

\section{Need to Know Does Not Equal Nice to Know}

Taking into account general norms and values, what is legally permitted and professionally allowed, the question remains what information can be shared. Chaplains who chart in patient files take into consideration the following ground rules: (1) The shared information is always in the best interest of the patient. Confidential information should be documented only with the consent of the patient. (2) Chaplains only share information if it contributes to the best overall, coordinated care and the wellbeing of the patient. This also applies to confidential information coming from family/ loved ones. Depending on local regulations, the patient may be entitled to see the chaplain's notes.

\section{Conditions for Research}

To be able to do quantitative and qualitative research on the charted data (check boxes and free text fields) it is important that there is uniformity in categories of charting, also among different care sectors, within a country and within Europe. Collecting patient files for research should meet the ethical research rules of the care facility, the country and the European regulations. Training of chaplains to chart in the same way is important so that notes will be rich and comparable.

\section{E. Language, Quality Improvement, Education and Training}

Charting contributes to the visibility of chaplaincy in healthcare. Essential is that charting is short, concise, clear and easy to access. To achieve this, chaplains need to learn, develop and use a language that clearly communicates what chaplaincy contributes to overall care. Charting is a way to improve quality of spiritual care as chaplains need to reflect on their practice. Based on the charted interventions and outcomes, training and education of chaplains and healthcare staff can be informed.

We recommend that chaplaincies evolve towards charting as a way to improve the quality of care for patients and families, to increase reflection on their actions and to advance integration in healthcare. On that path ERICH will work further towards standardized charting by doing research on interventions of chaplains and an appropriate language. 


\section{What Research Has Been Done and Needs to be Done?}

Healthcare chaplains carry out their work in a complex clinical environment defined by a professional ethics which valorizes evidence-based decision-making, accountability and transparency in order to provide the best possible care. Through their participation in institutional record keeping, chaplains can participate in this professional context, making their work more visible, understood, and accessible. Research can help improve this integration and has been growing in recent years. The following is a brief summary of research findings thus far:

\section{A. Conceptual Differentiation Between Forms of Confidentiality}

As Ruff (1996) argued in his work "Leaving footprints", chaplains leave traces of their work through their notes. Ruff also spoke of the professional need for the "visibility of chaplains". It was in 2007, that this "visibility of chaplains" led to a heated debate revolving around the professional identity of healthcare chaplains (McCurdy, 2012; Springer Loewy \& Loewy, 2007). Wintz and Handzo (2015), drew attention to the differences between parish clergy and healthcare chaplains. They defined "clergy confidentiality" as referring to the "information that someone seeking forgiveness shares with a clergyperson within the context of ritual confession". As ritual confession only plays a marginal role in the work of healthcare chaplains, the reference to "clergy confidentiality" is misleading. They point to the standards of the Association of Professional Chaplains (USA), which state that the passing on of information is allowed if it is "relevant to the patient's medical, psycho-social, and spiritual/religious goals of care". In the same vein, Alex Liégeois speaks of the "application of the relevance filter" (Liégeois, 2010, p. 93). Only information relevant for interprofessional care should be recorded (Vandenhoeck, 2020).

\section{Main research insights}

1. By charting their interactions with patients, healthcare chaplains leave important footprints, enhancing their visibility and accountability, while improving communication in the interprofessional team and encouraging ongoing professional self-reflection and -improvement.

2. Healthcare chaplains have to define their own understanding of confidentiality and distinguish it from «clergy confidentiality».

3. Being solely a means, documentation must serve the best care of the patient. 


\section{B. Check-boxes or Narratives?}

In developing models and tools for record keeping, printed and electronic forms typically provide chaplains with two options: narratives or checkboxes (Mösli, Neuhold, \& Wey-Meier, 2020). The above question touches on an important aspect of spiritual care. In his paper "Pastoral Products or Pastoral Care?", Tarris D. Rosell (2006) referred specifically to the terminology used in charting and the power of language to both describe and create realities. Burkhart (2011) discussed the advantages and disadvantages of a Likert scaled flowsheet with fixed categories compared to progress notes. While the checkbox-approach saves time and is more discreet, these are unsuitable for conveying clinically relevant information in a reader-friendly way.

Johnson et al. (2016) advocate the development of new language skills and the cultivation of clarity so that the work of chaplains can be properly understood and accessible for later reference. Lee et al. (2017) questioned the usefulness of chaplaincy electronic medical record notes for interprofessional communication. For, "documentation should provide clinically relevant communication", and has to be interprofessionally oriented and relevant. What healthcare providers would like to read and what can, should or may be written is an important question when working in an interprofessional context. As Galchutt and Connolly (2020) show, it is important to address underlying assumptions and perceptions of those who read healthcare chaplains notes, in particular medical professionals without specific spiritual competencies. Another research topic could map out what other healthcare professionals think about chaplains charting.

\section{Main research insights}

1. Chaplains' documentation should include only clinically relevant information, avoiding the danger of overloading the patient healthcare record with extraneous and repetitive data.

2. Using a balanced combination of checkbox-data and short, structured narratives is most useful for effective patient care.

3. Interprofessionally-oriented documentation affords specific language skills, the cultivation of clarity and addressing assumptions and perceptions within the whole care team.

\section{What Do Patients Think About Charting?}

In Switzerland Tschannen et al. (2014) surveyed 50 patients about their general attitudes towards charting by healthcare chaplains. At the end of the visit, chaplains summarized what they would chart and asked for patient's permission. About $70 \%$ of the respondents considered it desirable. Patients 
who were more pessimistic about their health status were more inclined to find the disclosure problematic. Remarkably, this study also found that patients' answers were connected with the person of the chaplain-interviewer. In order to measure the impact of chaplains' interventions and consequently the clinical and strategic worth of chaplaincy, Snowden and Telfer (2017) introduced PROMs (patient reported outcome measures) in the Scottish healthcare context. Feed-back from patients is important. Even more patient participation and involvement is gained where shared or open notes have been used (Richards et al., 2021), that is, that patients get insight in what has been written. In a process of so-called "co-writing", the patients" notes could even become more important in the future of whole person care. More research needs to be done regarding charting and the informed consent patients give to chaplains. Does the informed consent need to be explicit and only for confidential information? How can the informed consent be made visible in the patient's chart?

\section{Main research insights}

1. It seems necessary and important that patients are informed with regards to documentation.

2. In an evidence-based environment, patients' feedback is important to attest to a certain difference chaplains make.

3. More patient participation in charting could empower patients own perspectives in diagnosis and care planning.

\section{Acknowledgements}

The authors would like to thank Dr. Lindsay Carey, HSCC Editor-in-Chief, for assisting with the editing of this paper.

\section{References}

Balboni, T. A., Fitchett, G., Handzo, G. F., Johnson, K. S., Koenig, H. G., Pargament, K. I., Puchalski, C. M., Sinclair, S., Taylor, E. J., \& Steinhauser, K. E. (2017). State of the science of spirituality and palliative care research part II: Screening, assessment, and interventions. Journal of Pain and Symptom Management, 54(3), 441-453. https://doi.org/10.1016/ j.jpainsymman.2017.07.029

Burkhart, L. (2011). Documenting the story: Communication within a healthcare team, Vision, 21(3), 28-33.

Carey, L. B., \& Cohen, J. (2015). The utility of the WHO ICD-10-AM pastoral intervention codings within religious, pastoral and spiritual care research. Journal of Religion and Health, 54(5), 1772-1787. https://doi.org/10.1007/s10943-014-9938-8

Dicks, R. L. (1940). Standards for the Work of the Chaplain in the General Hospital. Hospitals, November. 
Galchutt, P., \& Connolly, J. (2020). Palliative chaplain spiritual assessment progress notes. In Peng-Keller, S., Neuhold, D. (Eds.), Charting spiritual care: The emerging role of chaplaincy records in global healthcare (pp. 181-198). Cham: Springer. https://doi.org/10.1007/ 978-3-030-47070-8 11

Johnson, R. M., Wirpsa, J., Boyken, L., Sakumoto, M., Handzo, G., Kho, A., \& Emanuel, L. (2016). Communicating chaplains' care: Narrative documentation in a neurosciencespine intensive care unit. Journal of Healthcare Chaplaincy, 22(4), 133-150. https://doi. org/ $10.1080 / 08854726.2016 .1154717$

Liégeois, A. (2010). Le conseiller spirituel et le partage d'informations en soins de santé. Un plaidoyer pour un secret professionnel partagé. Counseling et Spiritualité, 29(2), 85-97. https://resspir.org/wp-content/uploads/2018/11/Liégeois-Conseiller-spirituel-etpartage-dinformations-CounsSpirit-2010.pdf

Massey, K., Barnes, M., Villines, D., Goldstein, J., Pierson, A., Schere, C., Van der Laan, B., \& Summerfelt, W. (2015). What do I do? Developing a taxonomy of chaplaincy activities and interventions for spiritual care in intensive care unit palliative care. BMC Palliative Care, 14(10), 1-8. https://doi.org/10.1186/s12904-015-0008-0

McCurdy, D. B. (2012). Chaplains, confidentiality and the chart. Chaplaincy Today, 28(2). https://doi.org/10.1080/10999183.2012.10767458

Ministère de la Santé et des Services sociaux du Québec (2010). Orientations ministérielles pour l'organisation du service d'animation spirituelle en établissements de santé et de services sociaux. Ministère de la santé et des services sociaux du Québec.

Montonye, M., \& Calderone, S. (2010). Pastoral interventions and the influence of selfreporting: A preliminary analysis, Journal of Healthcare Chaplaincy, 16, 65-73. https:// doi.org/10.1080/08854720903519976

Mösli, P., Neuhold, D., \& Wey-Meier, L. (2020). Ankreuzen oder erzählen? Ein Plädoyer für Check-Boxes in der klinischen Seelsorgedokumentation. In Peng-Keller, S., Neuhold, D., Kunz, R., \& Schmitt, H. (Eds.), Dokumentation als seelsorgliche Aufgabe. Elektronische Patientendossiers im Kontext von Spiritual Care (pp. 127-149). Zürich: TVZ. https:// www.tvz-verlag.ch/_files_media/open_access/9783290183264.pdf

Peng-Keller, S., \& Neuhold, D. (Eds.) (2020). Charting spiritual care: The emerging role of chaplaincy records in global healthcare. Zurich: Springer Nature. https://doi.org/10.1007/ 978-3-030-47070-8

Richards, S., Carlson, K., Matthias, T., \& Birge, J. (2021). Perception versus reality: Does provider documentation behavior change when clinic notes are shared electronically with patients? International Journal of Medical Informatics, 145, 104304. https://doi. org/10.1016/j.ijmedinf.2020.104304

Rosell, T. D. (2006). Pastoral products or pastoral care? How marketplace language affects ministry in veterans hospitals. Journal of Pastoral Care and Counseling, 60(4), 363-367. https://doi.org/10.1177/154230500606000405

Ross, L., Grimwade, L., \& Eagger, S. (in press). Spiritual Assessment. In Cook, C. C. H., \& Powell, A. (Eds.) Spirituality and Psychiatry, 2nd Edn. Cambridge: Cambridge University Press.

Ross, L., \& McSherry, W. (2010). Considerations for the future of spiritual assessment. In McSherry, W., \& Ross, L. (Eds.) Spiritual assessment in healthcare practice (pp. 161-171). Keswick: M\&K Publishing.

Ross, L., \& McSherry, W. (2018). The power of two simple questions. Nursing Standard, 33(9), 78-80. https://doi.org/10.7748/ns.33.9.78.s22

Ross, L., \& McSherry, W. (2020). Spiritual care charting/documenting/recording/assessment: A perspective from the United Kingdom. In Peng-Keller, S., \& Neuhold, D. (Eds.) Charting spiritual care: The emerging role of chaplaincy records in global healthcare (pp. 
153-171). Cham: Springer. https://link.springer.com/content/pdf/10.1007\%2F978-3-03047070-8.pdf

Ross, L., \& Miles, J. (2020). Spirituality in heart failure: A review of the literature from 2014 to 2019 to identify spiritual care needs and spiritual interventions. Current Opinion in Supportive and Palliative Care, 14(1), 9-18. https://doi.org/10.1097/SPC.0000000000000475

Ruff, R. A. (1996). "Leaving footprints." The practice and benefits of hospital chaplains documenting pastoral care activities in patients' medical records. Journal of Pastoral Care and Counseling, 50(4), 383-391. https://doi.org/10.1177/002234099605000407

Smeets, W., Gribnau, F. W. J., \& van der Ven, J. A. (2011). Quality assurance and spiritual care. Journal of Empirical Theology, 24(1), 80-121. https://doi.org/10.1007/978-3-030-47070-8_ 7

Smeets, W., \& de Vries, A. (2016). Spiritual screening in a secular context. In Elsdörfer, U., \& Ito, T. D. (Eds.), Compassion for one another in the global village. Social and cultural approaches to care and counselling (pp. 92-99). Wien: LIT.

Smeets, W., \& de Vries, A. (2020). Spiritual care and electronic medical recording in Dutch hospitals. In Peng-Keller, S., \& Neuhold, D. (Eds.), Charting spiritual care: The emerging role of chaplaincy records in global healthcare (pp. 117-125). Cham: Springer. https:// link.springer.com/content/pdf/10.1007\%2F978-3-030-47070-8.pdf

Snowden, A., Enang, I., Kernohan, W. G., Fraser, D., Gibbon, A., Macritchie, I., McSherry, W., Ross, L., \& Swinton, J. (2020). Why are some healthcare chaplains registered professionals and some are not? A survey of healthcare chaplains in Scotland. Journal of Health and Social Care Chaplaincy, 8(1), 45-69. https://doi.org/10.1558/hscc.39783

Snowden, A., \& Telfer, I. (2017). Patient reported outcome measure of spiritual care as delivered by chaplains. Journal of Healthcare Chaplaincy, 23(4), 131-155. https://doi.org/10.1 080/08854726.2017.1279935

Springer Loewy. R., \& Loewy, E. H. (2007). Healthcare and the Hospital Chaplain. Medscape General Medicine, 9(1). https://www.ncbi.nlm.nih.gov/pmc/articles/PMC1924976/

Steinhauser, K. E., Fitchett, G., Handzo, G. F., Johnson, K. S., Koenig, H. G., Pargament, K. I., Puchalski, C. M., Sinclair, S., Taylor, E. J., \& Balboni, T. A. (2017). State of the science of spirituality and palliative care research part I: Definitions, measurement, and outcomes. Journal of Pain and Symptom Management, 54(3), 428-440. https://doi.org/ 10.1016/j.jpainsymman.2017.07.028

Tschannen, O., Chenuz, P., Maire, D. E., Petremand, D., Vollenweider, P., \& Odier, C. (2014). Transmission d'informations par les aumôniers dans le dossier-patient: le choix des patients. Forum Med Suisse, 14(49), 924-926.

Vandenhoeck, A. (2020). The spiritual care giver as a bearer of stories: A Belgian exploration of the best possible spiritual care. In Peng-Keller, S., \& Neuhold, D. (Eds.), Charting spiritual care: The emerging role of chaplaincy records in global healthcare (pp. 129-144). Cham: Springer. https://doi.org/10.1007/978-3-030-47070-8_8

Wintz, S., \& Handzo, G. (2015). Dokumentation und Verschwiegenheit in der professionellen Seelsorge. Wege zum Menschen, 67(2), 160-164. (English version at http://www.handzoconsulting.com/blog/2013/9/19/documentation-and-confidentiality-for-chaplains. html.)

World Health Organization (2002). ICD-10 AM International Statistical Classification of Diseases and Related Health Problems 10th Revision Australian Modification. World Health Organization. 


\section{Annex 1: Discussion of the White Paper During The Consultation Of ENHCC}

\section{Reception of the White Paper}

The online consultation of ENHCC was attended by 91 participants from the following parts of Europe: Austria, Belgium, Cyprus, Czech Republic, Denmark, England, Estonia, Finland, France, Germany, Greece, Hungary, Ireland, Italy, Northern Ireland, Norway, Latvia, Luxemburg, Portugal, Romania, Scotland, Sweden, Switzerland, The Netherlands and Vatican State. The participants are chaplains or/and representatives of professional associations for chaplains or of churches or faith communities. Participants received the White Paper some weeks before the consultation took place, giving them the opportunity to go through the document. On 14 May 2021, the White Paper was introduced and discussed in small groups and on Padlet during the third and final day of the consultation.

Chaplains who embraced the White Paper with enthusiasm, did so for reasons of opportunities for advocacy and increased reflection on the profession, training and education prospects and other professional concerns like more transparency and visibility. Chaplains who welcomed the White Paper tended to express more advantages of charting. They mentioned the impact of charting on referrals, accountability, recognition of the chaplain, safety of staff and patients, continuity of care.

Some chaplains were more hesitant in their reception of the White Paper. Not all chaplains have access to electronic patient notes. Not all chaplains are hired by healthcare facilities, some are sent by their religious communities or faith organizations. Not all chaplains have the same understanding of their role. Some chaplains form their identity based on not being integrated and not charting. A chaplain expressed not being integrated as a way to keep integrity. Other chaplains stressed the importance of strict confidentiality, looking at the chaplain with the same criteria and expectations as to priests, vicars and reverends in community settings. A chaplain clearly stated that the White Paper is not critical enough regarding the confidentiality issue. One participant wrote that chaplains feel loyalty to their churches who stress confidentiality in matters of spiritual conversations with people. Another participant advocated for promoting the White Paper to leaderships of churches as it is important they are aware of what is happening in chaplaincy regarding charting and confidentiality.

The differences in reception of the White Paper once more emphasized the differences in chaplaincy throughout Europe. The integration of spiritual care varies across Europe. The religious/faith history of a country, civil 
laws, the ways chaplaincy is organized on the level of healthcare institutions and on national levels are the root causes of the differences. One participant wrote, for example, that in countries with a communist past charting sometimes is looked upon with suspicion. Another participant mentioned the difference between healthcare sections regarding opportunities for charting. And yet another participant referred to different legal frameworks across countries.

Next to their position towards the White Paper, chaplains also expressed some concerns regarding charting, the need for more research and the need for more concrete guidance. In the feedback, four main concerns can be distinguished regarding charting: 1) The use of language. Chaplains advocate for a simple, everyday language which stays close to the needs of patients (for example by using their words whenever appropriate). Yet, the language used should also express the difference between spiritual care and other forms of care. 2) The content of what is written. Some chaplains stress the importance of writing as if the patient is looking over your shoulder. Others advocate for making what you chart part of the conversation with the patient. One participant wonders how overlap in patient information can be avoided between disciplines, as charting takes time. Yes, charting takes time, but it is worth it, writes another participant. One chaplain adds that nurses or physicians have no opportunity to say they don't have time to chart. 3) Chaplains worry about the tension between confidentiality and charting. Some chaplains make a case for private notes (on the condition they are stored safely) or for a part in the electronic patient file that is not accessible to others. Others reflect on the consent of patients or advocate for stricter rules on shared confidentiality in a healthcare team.

The reception of the White Paper during the consultation also expressed the need for more research which would lead to standardized charting, to more insights in what kind of consent of the patient is needed for what and to a taxonomy that fits within the European context. Lastly, chaplains expressed the need for more concrete tools: a clear pathway for charting based on a taxonomy, a shorter version of the White Paper for management in non-jargon, sharing different formats so chaplains can choose whatever works best for their context, standardized charting.

\section{Good experiences and practices of charting by the participants of the consultation}

Some chaplains noted good experiences and practices of charting. The experiences and practices were shared on Padlet during the consultation. Some vignettes may inspire other chaplains: 
"On some wards in our hospital, during the briefings, they display the 'dashboard' of the electronic patient file, so they can all see the follow up of all disciplines, also these of the chaplains. It makes our contribution very visible."

"I have good experiences with colleagues recording spiritual needs of residents and then referring to me via the electronic patient file."

"I see that it is a way to be part of a transdisciplinary team. People of the team are not reading all, but at some points you get a referral 'because I know you go to residents who are grieving."”

"Charting keeps structure in the work and in the day."

"Seeing chaplaincy mentioned in the file makes clear to all other professionals that the chaplain is part of the care."

"It is important not to use a psychological diagnosis but to focus on pastoral issues in order to make the difference between the disciplines clear."

"Charting makes me think about what I did (or had to do), what I have seen (or didn't see) during my intervention."

"Ideally, charting is part of the process I go with the patient as we both agree on what will be written and how."

"Charting helps to nuance things. A nurse wrote: 'patient says he wants to die'. As a chaplain I wrote: 'No active death wish but patient is very tired, still feels the power to fight when his family is with him but sometimes emotions overwhelm him."

"It is very important to refer to the patient with their preferred name."

"Charting is a very good way to respond to a referral. If we are asked to see a patient, then we should document our response, interventions, outcome."

"From my experience of charting on MDT Bereavement Team - it is invaluable for consistency of practice as we are one team."

"A physician told me: 'Seeing your note reminded me that the patient in bed 8 is more than just his condition."

"Using the words of the patients their selves helps the multidisciplinary team to stay close to their needs."

"I write down my observations which allows me to keep what the patient said confidential."

"It helps writing as if the patient would look over my shoulder. It enhances taking distance from my own feelings and changes the way I will proceed with care."

"Through personal documentation using selected questions, I have been able to look at my counseling sessions in a more focused way and figure out for myself which interventions are really helpful and which are not."

"For the open-access part of our charting, we always ask one question: Is this a necessary and chaplaincy-specific contribution we make to whole person care?" 